\title{
Shallow groundwater nitrogen responses to different land use managements in the riparian zone of Yuqiao Reservoir in North China
}

\author{
LU Haiming ${ }^{1,2}$, YIN Chengqing ${ }^{1, *}$ \\ 1. Research Center for Eco-Environmental Sciences, Chinese Academy of Sciences, Beijing 100085, China. E-mail: cnlhm@ 126.com \\ 2. Nanjing Hydraulic Research Institute, State Key Laboratory of Hydrology-Water Resources and Hydraulic Engineering, Nanjing 210029, China
}

Received 16 March 2007; revised 7 June 2007; accepted 25 January 2008

\begin{abstract}
This field study investigated the nitrogen concentrations in the shallow groundwater from an ephemeral stream and four land uses: cropland, two-year restored (2yr) and five-years restored (5yr) woodlands, fishponds, and the nitrogen flux in the riparian zone of Yuqiao Reservoir. The groundwater nitrate-N concentrations in cropland were the highest among the four land uses. Total dissolved nitrogen (TDN) and nitrate-N concentrations in the $2 \mathrm{yr}$ woodland were significantly $(p<0.05)$ higher than in $5 \mathrm{yr}$ woodland. The lowest nitrogen concentrations were detected in fishponds. Nitrate- $\mathrm{N}$ was the main form in cropland and $2 \mathrm{yr}$ woodland, whereas both nitrate- $\mathrm{N}$ and dissolved organic nitrogen (DON) were the main species in $5 \mathrm{yr}$ woodland and fishponds. But, ammonium- $\mathrm{N}$ was the main form in the ephemeral stream. During the rainy season, the groundwater flow with dissolved nitrogen drains from upland into the reservoir along the hydraulic gradient. The woodland between the cropland and reservoir could act as a buffer to retain shallow groundwater nitrogen. The dominant form of ammonium- $\mathrm{N}$ in the groundwater TDN pool in ephemeral stream indicated that nitrogen from the village and orchard in upland flowed into the reservoir via subsurface flow. The fishpond was not an important pollution source for nitrogen transfer via shallow groundwater.
\end{abstract}

Key words: nitrogen; groundwater; reservoir; fishpond; cropland; woodland; riparian zone

\section{Introduction}

Nitrogen contamination from surface water and groundwater causes a host of problems by degrading the drinking water supplies (Zhang et al., 1996; Haag and Kaupenjohann, 2001) and impairing ecological function of aquatic ecosystem (Eickhout et al., 2006). The excessive application of fertilizer and manure in agro-ecosystems has been shown to be the primary nitrogen contributor (Wang et al., 2003; Almasri and Kaluarachchi, 2004; Ju et al., 2006), whereas riparian buffer zones vegetated with trees, scrub, or grass could serve as nutrient filters to remove nitrogen (Groffman et al., 1998; Cey et al., 1999).

The nitrogen buffering capacity of riparian zones is known to be controlled by two main processes: denitrification and plant uptake. Research on these processes has focused on the hydrogeochemical processes in the stream riparian zone or the river floodplain, where surface water level often fluctuates at the scales of hours, days or weeks (Takatert et al., 1999; Martin et al., 2004; Rassam et al., 2006). However, little research is done on the riparian zone of reservoirs, where surface water level only changes seasonally and is mainly adjusted for flood management and maintenance of water supply. Furthermore, because of the high demand for food and economic development

\footnotetext{
* Corresponding author. E-mail: cqyin@263.net.
}

in China, the riparian areas of many reservoirs have been converted into other land uses (e.g., cropland, fishpond) after the historical reclamation practices, which might pose great risks to the water quality. Because reservoirs are often the primary sources of drinking water supply for many cities in China, prevention of eutrophication has important implications on people's health.

A previous study conducted in the same research area showed that the mean annual runoff coefficient was only 0.0016 , indicating that much rainfall infiltrated into the ground (Lu et al., 2007). So it is important to understand the nitrogen pattern and flux in the shallow groundwater in the riparian with different land uses. This study was conducted to investigate the nitrogen status in the shallow groundwater in croplands, fishponds, and woodlands in the riparian zone of Yuqiao Reservoir to protect the reservoir water more efficiently.

\section{Materials and methods}

\subsection{Study area}

Yuqiao Reservoir locates in the northeast of Tianjin City, China. Cropland, woodland, and fishpond are the main land use types in the riparian zone, where a few villages and farmyards are present. Average annual precipitation is 
$601 \mathrm{~mm}$, of which approximately $70 \%$ occurs in June, July, and August. The monthly precipitation in the study year of 2005 during these seasons was $99.8,126.4$, and 215.8 $\mathrm{mm}$, respectively. The climate is temperate and territorially semi-arid. Other information on the studied catchment can be found in the published works (Lu et al., 2007).

Our study site is located in the lower part of Taohuasi catchment (Fig.1) on the north bank of Yuqiao Reservoir. An ephemeral stream has developed from an incised gully, which transfers water and nutrients from the upland to the reservoir during the rainy seasons. Much of water infiltrates into the ground and then flows into the reservoir as subsurface flow because of the roughness in complex surface. An irrigation canal was also built to draw the reservoir water.

\subsection{Water sampling and measurement}

\subsubsection{Sampling sites}

A network of eleven sampling sites in croplands, twoyear restored (2yr) and five-year restored (5yr) woodlands, and fishponds were selected to compare groundwater nitrogen status (Fig.1). Four of them (5, 10, 11, and 12) were located in the intensively cultivated cropland, with the use of relatively high load (300-500 kg/ $\mathrm{hm}^{2}$ as $\mathrm{N}$ element) of mineral fertilizers (synthetic nitrogen fertilizers, such as urea or commercial composite fertilizers) and manures (livestock waste). The main crops were maize and wheat.

To compare subsurface nitrogen in different age forests, two of the sampling sites were selected in $2 \mathrm{yr}$ woodland (W2Y) (Sites 4 and 8) and 5yr woodland (W5Y) (Sites 6 and 9), respectively. The woodlands were intensively planted with crop production before the restoration.

The sampling sites 1,2 , and 3 were selected in the

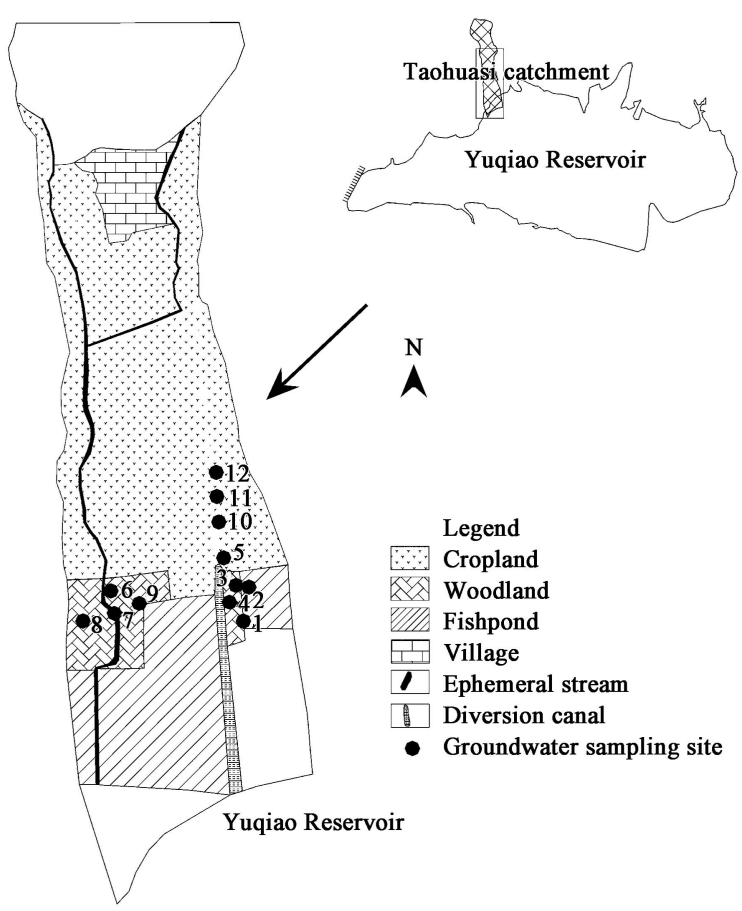

Fig. 1 Location of the study catchment and groundwater sampling sites. fishpond. The sampling sites 1 and 3 were located outside the earth ridge of fish pond, and the site 2 inside the earth ridge. The fishponds were built approximately ten years ago. They were cleaned every two or three years.

The sampling site 7 was located in the ephemeral stream across the woodland to monitor the water and nitrogen flux via subsurface flow.

\subsubsection{Sampling procedure}

The monitoring wells (3.2-cm diameter PVC tubes) at three layers $(2,3$, and $4 \mathrm{~m}$ depths below the ground surface), spaced approximately $10 \mathrm{~cm}$ apart, were installed at each sampling site. The lengths of PVC tubes were 2, 3 , and $4 \mathrm{~m}$, respectively, for the corresponding sampling depths. Ten centimeters PVC tube, lay between 20-30 $\mathrm{cm}$ away from the bottom, was slotted and wrapped with $0.22 \mathrm{~mm}$ nylon mesh for the groundwater percolation. The bottom was sealed to collect the groundwater samples. After the installation, all wells were purged several times with a hand-held vacuum pump to remove the sediment. During the sampling intervals, the top was sealed by a rubber cap.

The groundwater samples were generally collected within $24 \mathrm{~h}$ after the previous water was pumped out using a hand-held vacuum pump. For each sample, the groundwater wells were pumped out and the volumes of groundwater collected were also recorded. The water samples were put into polyethylene bottles, filtered through a $0.45-\mu \mathrm{m}$ micropore membrane in the laboratory, and stored in the dark at $4^{\circ} \mathrm{C}$ until chemical analysis was carried out (less than $4 \mathrm{~d}$ ). The groundwater table and surface water table in the reservoir were also recorded when the groundwater samples were taken.

\subsubsection{Chemical measurement}

Total dissolved nitrogen (TDN) was measured by mineralization $\left(120^{\circ} \mathrm{C}\right.$ for $\left.30 \mathrm{~min}\right)$ in an alkaline solution $(\mathrm{NaOH})$ with potassium persulphate as catalyzer for the filtered water samples (Ebina et al., 1983). The concentrations of ammonium-N $\left(\mathrm{NH}_{4}{ }^{+}-\mathrm{N}\right)$ and nitrate- $\mathrm{N}\left(\mathrm{NO}_{3}{ }^{-}-\mathrm{N}\right)$ were determined by a colorimetric method. The procedures used are specified in APHA (1985): $\mathrm{NH}_{4}{ }^{+}-\mathrm{N}$ was determined with the indophenol blue method and $\mathrm{NO}_{3}{ }^{-}-\mathrm{N}$ with the cadmium reduction method. Dissolved organic nitrogen (DON) was calculated as the difference between TDN and the total concentration of inorganic nitrogen forms $\left(\mathrm{NH}_{4}{ }^{+}-\mathrm{N}\right.$ and $\left.\mathrm{NO}_{3}{ }^{-}-\mathrm{N}\right)$.

\subsubsection{Statistical analysis}

To compare nitrogen concentrations between different land uses, the normal distribution of all the variables were tested using the Kolmogorov-Smirnov test. For the normally distributed data, one-way ANOVA Post Hoc test (LSD method) was used, the mean value was calculated for the samples. Otherwise, nonparametrical Mann-Whitney U and Kruskal-Wallis Post Hoc tests were used, the median values were given. The above statistical analysis was carried out using SPSS 11.0 (SPSS Inc., USA), with a significance determined at $p<0.05$. 


\section{Results}

\subsection{Temporal variation of reservoir water and ground- water table}

The relationship between the groundwater table and surface water table in the reservoir could be separated into two phases (Fig.2). During the rainy season (June, July, and August), the groundwater table was higher than the surface water table in the reservoir. During the dry season, the water table was similar in the groundwater and reservoir water. This result indicated that the groundwater recharge was provided by the precipitation. The water table variation from the riparian zone to the reservoir between the rainy season and the nonrainy season are shown in Fig.3.

\subsection{Groundwater nitrogen concentrations in different land uses}

Significant differences were detected in the nitrogen concentrations among the four land uses (Fig.4). The cropland presented the highest median values of TDN,

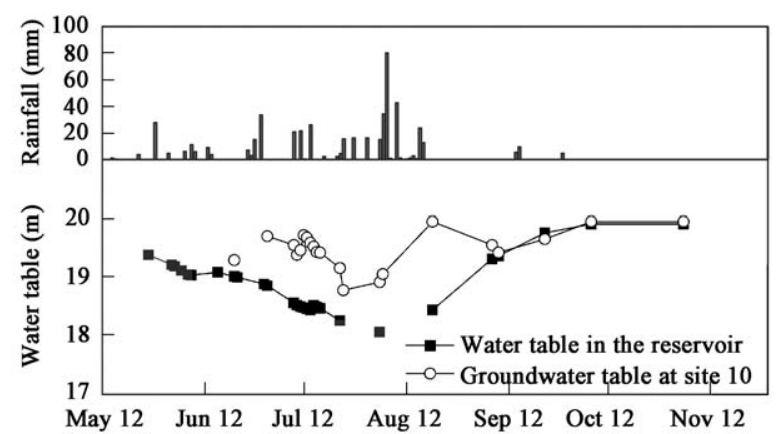

Fig. 2 Daily precipitation, reservoir water table, and groundwater table during the study period.
nitrate-N, and dissolved organic nitrogen (DON) concentrations. Nitrate- $\mathrm{N}$ was the main form of TDN in the cropland and W2Y. The median value of nitrate-N $(6.67 \mathrm{mg} / \mathrm{L})$ in the cropland was 10.8 times higher than that $(0.62 \mathrm{mg} / \mathrm{L})$ of $\mathrm{W} 2 \mathrm{Y}$, the second highest nitrate- $\mathrm{N}$ concentrations. W5Y and the fishpond sites showed the lowest concentrations for all the tested nitrogen species, among which nitrate-N and DON were the main species. For the cropland, approximately $13 \%$ of the observed nitrate- $\mathrm{N}$ concentrations exceeded the national drinking water standard $(20 \mathrm{mg} / \mathrm{L})$, and $39 \%$ of them exceeded the USEPA maximum contaminant level (MCL) (10 mg/L).

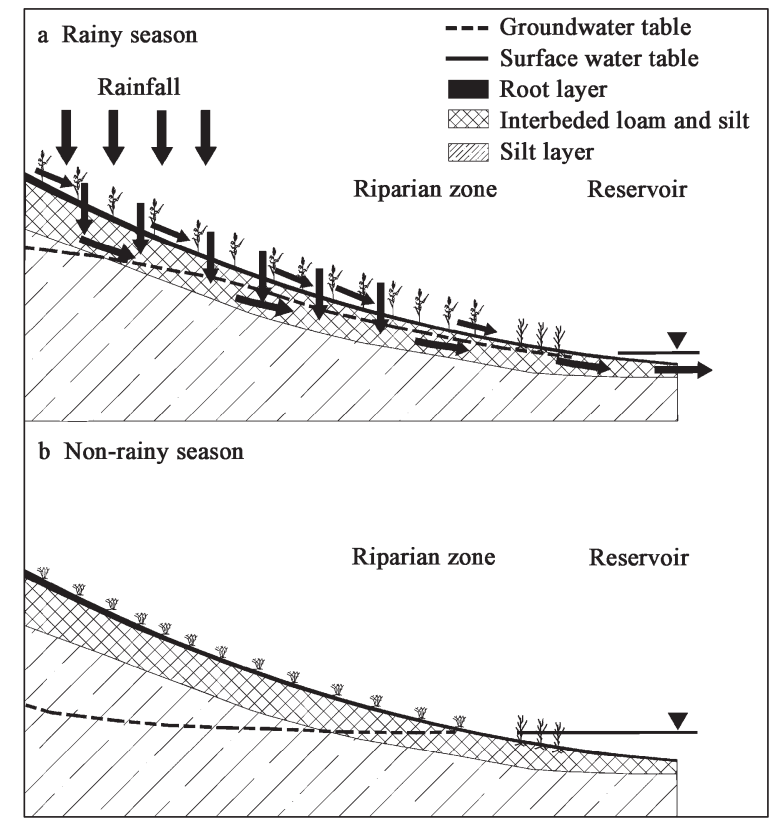

Fig. 3 Longitudinal section showing the difference of the groundwater table and surface water table in rainy season and nonrainy season.
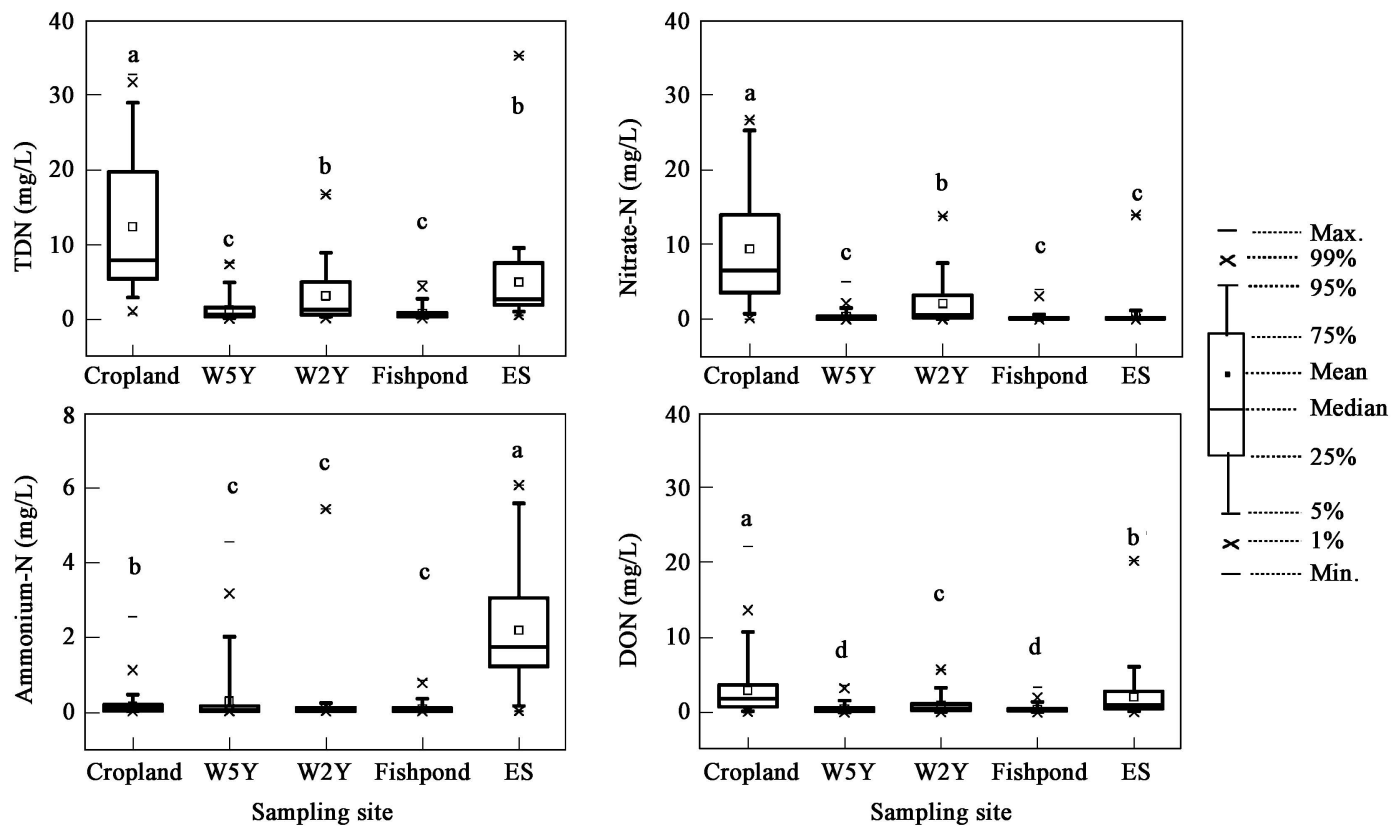

Fig. 4 Comparison of the groundwater nitrogen concentrations among the four land uses. Different letters (a, b, c, d) above the box indicate a significant difference $(p<0.05)$. The statistical analysis was carried out using the nonparametric test and the Mann-Whitney U test. W5Y: five-year restored woodland; W2Y: two-year restored woodland; ES: the ephemeral stream. 


\subsection{Nitrogen status variation at different temporal} scales

During the study period, the concentrations of various nitrogen species showed complex variation at different temporal scales. Nitrate- $\mathrm{N}$ was significant in rainy season, which was higher than in dry season in the cropland (Fig.5). No significant difference was present in TDN between the rainy season and the nonrainy season for the all of the four land uses except for W2Y. All of the four land uses showed a significant difference in ammonium-N between the rainy season and the nonrainy season.

Nitrate-N at three depths in the cropland varied throughout the monitoring period (Fig.6). The higher concentrations were observed between July and August, and the lower concentrations were observed in September and October. A precipitation of $20.8 \mathrm{~mm}$ (Fig.7) on July 9th triggered a groundwater elevation peak after three days, whereas the nitrate-N peak at a 2-m depth was presented after five days. But the nitrate-N peak was not observed at 3-m depth and 4-m depth. Hence, it was assumed that the variation in the groundwater table and the nitrogen concentrations at 2-m depth was logically attributed to the

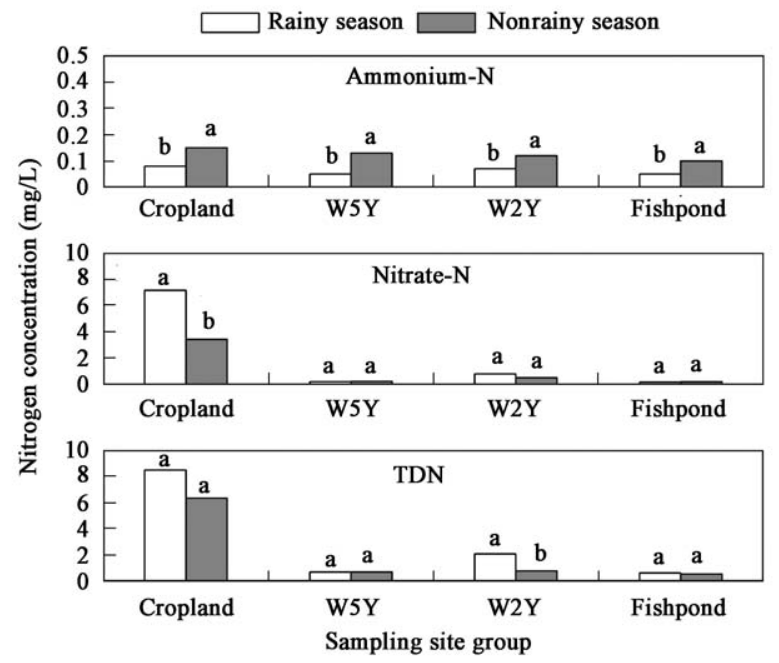

Fig. 5 Comparison of the nitrogen concentrations between rainy season and the nonrainy season for the four land uses. Different letters $(a, b)$ above the box indicate a significant difference $(p<0.05)$. The statistical analysis was carried out using the nonparametric test and the MannWhitney U test.

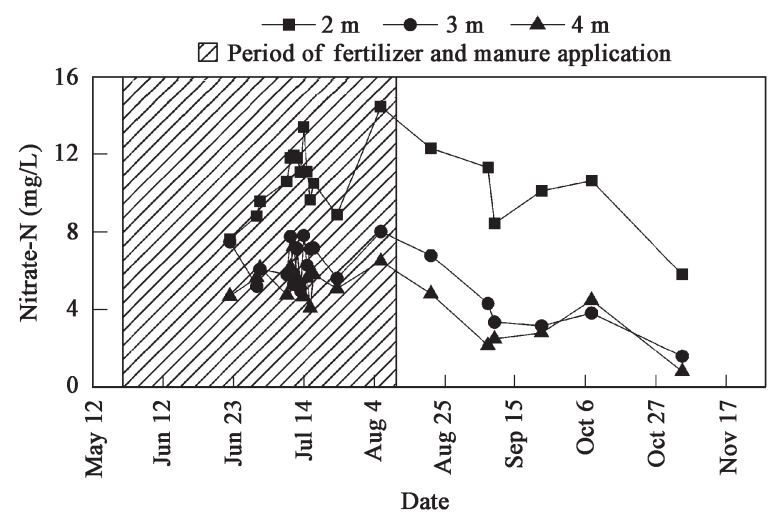

Fig. 6 Temporal variation of nitrate-N concentrations at three depths of the sampling site 10 in the cropland during the study period. interflow caused by the rainstorm. As the groundwater is shallow, it is affected by the surface runoff.

\subsection{Groundwater nitrogen status in the ephemeral stream}

Ammonium-N was the main form among the groundwater nitrogen pools in the ephemeral stream at three depths during most of the monitoring period (Table 1). Sometimes DON was the dominant species especially at $3 \mathrm{~m}$ depth. The median ammonium-N concentration was $1.75 \mathrm{mg} / \mathrm{L}$, which was significantly higher than that of other land uses $(p<0.05)$. Ammonium-N were higher at $3 \mathrm{~m}$ depth than at $2 \mathrm{~m}$ depth or $4 \mathrm{~m}$ depth, which indicated that ammonium$\mathrm{N}$ was easier to be transported via subsurface flow at $3 \mathrm{~m}$ depth than at other two depths.

\section{Discussion}

The water table gap between the groundwater in the riparian zone and the surface water in the reservoir created the hydraulic gradient, which flushed dissolved nutrient into the reservoir. During the rainy season, nitrate- $\mathrm{N}$ in the groundwater brought upland nitrogen loads into the reservoir via advection flow of the shallow groundwater associated with the hydraulic head. However, this advection process was terminated in the dry season because of a constant head between the riparian zone and the reservoir. The contribution of groundwater nitrate- $\mathrm{N}$ to the reservoir occurred primarily in the rainy season, as indicated by the different nitrate- $\mathrm{N}$ spatial patterns in the canal in the rainy and the nonrainy seasons. In the rainy season (e.g., July 7), nitrate- $\mathrm{N}$ decreased with the increasing distance from the canal end. The stratification phenomenon for nitrate- $\mathrm{N}$ was observed in the water profile near the riparian bank during the rainy season but was not observed during the dry season (e.g., November 4).

Many reports have indicated that the woodland in the riparian zone could effectively remove nutrients from the upland (Cey et al., 1999; Takatert et al., 1999; Clement et al., 2003). In our research, the woodlands were located at the lower slope of the croplands. Nitrate-N was also removed in the woodland, as indicated by the fact that nitrate- $\mathrm{N}$ in the woodland were lower than in the cropland. Moreover, nitrate-N in W5Y were lower than in W2Y, suggesting that the removal efficiency in the more mature

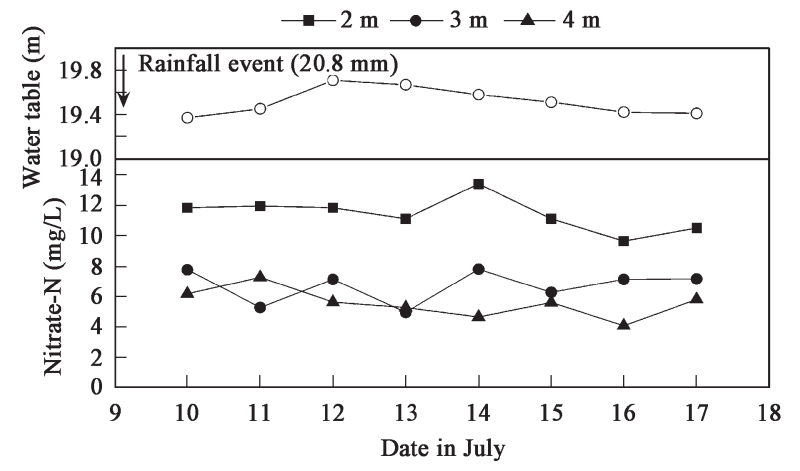

Fig. 7 Daily fluctuation of nitrate-N concentration and the groundwater table in the cropland (sampling site 10) after a precipitation event. 
Table 1 Temporal variation of groundwater nitrogen concentrations at three depths for the ephemeral stream $(\mathrm{mg} / \mathrm{L})$

\begin{tabular}{|c|c|c|c|c|c|c|c|c|c|}
\hline & \multicolumn{3}{|c|}{ Depth $2 \mathrm{~m}$} & \multicolumn{3}{|c|}{ Depth $3 \mathrm{~m}$} & \multicolumn{3}{|c|}{ Depth $4 \mathrm{~m}$} \\
\hline & $\mathrm{NO}_{3}{ }^{-}-\mathrm{N}$ & $\mathrm{NH}_{4}{ }^{+}-\mathrm{N}$ & DON & $\mathrm{NO}_{3}{ }^{-}-\mathrm{N}$ & $\mathrm{NH}_{4}^{+}-\mathrm{N}$ & DON & $\mathrm{NO}_{3}{ }^{-}-\mathrm{N}$ & $\mathrm{NH}_{4}^{+}-\mathrm{N}$ & DON \\
\hline 26-May & 0.21 & 1.58 & 0.16 & 0.93 & 6.05 & 0.27 & 0.17 & 4.02 & 0.07 \\
\hline 3-Jun & 0.15 & 1.76 & 0.34 & 0.18 & 3.43 & 4.44 & 0.13 & 1.45 & 1.30 \\
\hline 8-Jun & 0.04 & 0.70 & 0.95 & 0.15 & 3.05 & 4.57 & 0.04 & 1.27 & 1.21 \\
\hline 16-Jun & 0.04 & 1.23 & 0.47 & 0.22 & 3.98 & 2.55 & 0.16 & 1.59 & 0.39 \\
\hline 22-Jun & 0.30 & 0.61 & 0.20 & 0.54 & 3.86 & 2.36 & 0.27 & 1.71 & 0.10 \\
\hline 30-Jun & 0.05 & 0.18 & 0.46 & 0.25 & 3.73 & 3.69 & 0.18 & 1.87 & 0.87 \\
\hline 9-Jul & 0.05 & 0.70 & 1.35 & 0.26 & 4.52 & 3.73 & 0.34 & 2.25 & 1.33 \\
\hline 10-Jul & 0.24 & 0.91 & 0.55 & 0.59 & 4.34 & 4.13 & 0.27 & 1.98 & 0.35 \\
\hline 11-Jul & 0.26 & 1.99 & 0.48 & 0.17 & 4.39 & 2.97 & 0.27 & 1.94 & 0.53 \\
\hline 12-Jul & 0.17 & 1.12 & 0.50 & 0.38 & 4.62 & 7.06 & 0.32 & 2.04 & 0.54 \\
\hline 13-Jul & 0.17 & 1.79 & 0.05 & 0.32 & 5.34 & 4.46 & 0.80 & 1.98 & 0.46 \\
\hline 14-Jul & 0.04 & 2.06 & 0.35 & 0.26 & 6.06 & 1.85 & 0.45 & 1.33 & 0.84 \\
\hline 15-Jul & 0.04 & 1.73 & 0.80 & 0.18 & 5.85 & 2.85 & 0.72 & 1.84 & 1.22 \\
\hline 16-Jul & 0.13 & 1.37 & 0.51 & 0.11 & 5.58 & 2.80 & 0.04 & 1.55 & 1.99 \\
\hline 17-Jul & 0.18 & 1.27 & 0.47 & 0.05 & 5.77 & 2.61 & 0.14 & 0.39 & 0.48 \\
\hline 24-Jul & - & - & - & 0.05 & 5.01 & 2.07 & 0.05 & 1.65 & 0.81 \\
\hline 5-Aug & 0.15 & 0.62 & 0.48 & 0.19 & 4.05 & 4.62 & 0.10 & 1.56 & 1.49 \\
\hline 21-Aug & 0.05 & 2.45 & 0.03 & 2.14 & 5.20 & 2.17 & 0.10 & 1.47 & 1.37 \\
\hline 9-Sep & 0.36 & 1.00 & 0.98 & 0.25 & 6.09 & 2.70 & 0.25 & 1.28 & 1.36 \\
\hline
\end{tabular}

-: no water was collected.

woodland was higher than in the less mature woodland. So, woodlands should be restored for those areas where croplands were adjacent to the reservoir directly to protect the reservoir from the nitrogen contamination.

It is interesting that groundwater ammonium- $\mathrm{N}$ was the dominant form and ammonium- $\mathrm{N}$ in the ephemeral stream were significantly higher than in each of the four land uses $(p<0.05)$. We hypothesized that ammonium-N was originated from the villages and orchards in up-slope and sub-surface flow in the ephemeral stream could transfer ammonium-N from the upland into the reservoir after the ephemeral surface flow ceased. Lu et al. (2007) observed that the mean annual runoff coefficient in this catchment was very low. So, a large proportion of rainfall could infiltrate into ground. Heavy application of manures in the orchards and ammonium-N leakage from organic waste pond in the village could provide ammonium- $\mathrm{N}$ sources continuously. Moreover, during the developing process of the ephemeral stream from incised gully, cracks created by many stones with different sizes in the stream bed favored the water and nitrogen transport from the upland. When ammonium-N in shallow groundwater reached woodland, the anoxic environment created by high groundwater table was favorable to the existence of ammonium-N, as shown by other researchers (Takatert et al., 1999; Clement et al., 2003).

The groundwater nitrogen concentrations in the fishponds were lower than in other land uses, suggesting that groundwater nitrogen loss from the fishpond was not the main source to the reservoir. However, the nitrogen export via the fishpond surface water drainage into the reservoir needs careful management because the annual mean TDN concentration in the surface water of the fishpond was $5.82 \mathrm{mg} / \mathrm{L}$. When fishes were harvested and the fishpond sediment was removed, its surface water sometimes was drained into the reservoir directly. According to the other works, the fishpond area around the Yuqiao reservoir was approximately $100 \mathrm{hm}^{2}$. If the average drainage water depth was $1 \mathrm{~m}$ per year, the annual nitrogen export into the reservoir was estimated at approximately $5800 \mathrm{~kg}$, which was an important nitrogen source to the reservoir and should not be overlooked. To protect the water quality in the reservoir, the direct discharge of the fishpond surface water should be banned. The fishpond water could be used to irrigate the cropland and be used in other fishponds. Another alternative way is to construct wetlands to remove nutrients before being drained into the reservoir. If the water discharge from the fishpond into the reservoir could be prevented, the fishpond could be preserved to a certain extent.

\section{Conclusions}

Among the four land uses, the cropland presented the highest groundwater nitrogen concentrations because of higher fertilizer application. The groundwater nitrogen concentrations in $2 \mathrm{yr}$ woodland were significantly higher than in 5yr woodland. The shallow groundwater nitrogen concentrations in the fishponds were as low as those in 5yr woodland. Nitrate-N was the main form in the cropland and $2 \mathrm{yr}$ woodland, whereas nitrate-N and DON were the main forms in $5 \mathrm{yr}$ woodland and fishpond. The high ammonium-N concentrations in the ephemeral stream suggested that the nitrogen from the village and orchard in upland could also flux into the reservoir through subsurface flow in the ephemeral stream.

In those areas where the croplands are adjacent to the reservoir, the buffer zone such as woodlands should be developed to retain nutrients from upland in landscape planning. The very low groundwater nitrogen concentrations in fishponds suggested that nitrogen contribution via subsurface flow from fishponds was low.

\section{Acknowledgements}

This work was supported by the Key Project of Knowledge Innovation Programme of CAS (No. KZCX1-YW- 
06-02), the National Basic Research Priorities Program of China (No. 2006CB403306) and the National Natural Science Foundation of China (No. 40601036). We are grateful to the local farmers for their field assistance, to Desiree Tullos, and two anonymous reviewers for their helpful comments and language corrections of the manuscript.

\section{References}

Almasri M N, Kaluarachchi J J, 2004. Assessment and management of long-term nitrate pollution of ground water in agriculture-dominated watersheds. J Hydrol, 295(1-4): 225-245.

APHA, AWWA, WEF, 1985. Standard Methods for the Examination of Water and Wastewater (18th ed.). American Water Works Association, Washington DC. 373-412.

Cey E E, Rudolph D L, Aravena R, Parkin G, 1999. Role of the riparian zone in controlling the distribution and fate of agricultural nitrogen near a small stream in southern Ontario. J Contam Hydrol, 37(1-2): 45-67.

Clement J C, Aquilina L, Bour O, Plaine K, Burt T P, Pinay G, 2003. Hydrological flowpaths and nitrate removal rates within a riparian floodplain along a fourth-order stream in Brittany (France). Hydrol Process, 17(6): 1177-1195.

Ebina J, Tsutsui T, Shirai T, 1983. Simultaneous determination of total nitrogen and total phosphorus in water using peroxodisulfate oxidate. Water Res, 17: 1721-1726.

Eickhout B, Bouwman A F, van Zeijts H, 2006. The role of nitrogen in world food production and environmental sustainability. Agr Ecosyst Environ, 116(1-2): 4-14.

Groffman P M, Gold A J, Jacinthe P A, 1998. Nitrous oxide production in riparian zones and groundwater. Nutr Cycl
Agroecos, 52(2-3): 179-186.

Haag D, Kaupenjohann M, 2001. Landscape fate of nitrate fluxes and emissions in Central Europe-A critical review of concepts, data, and models for transport and retention. Agr Ecosyst Environ, 86(1): 1-21.

Ju X T, Kou C L, Zhang F S, Christie P, 2006. Nitrogen balance and groundwater nitrate contamination: Comparison among three intensive cropping systems on the North China Plain. Environ Pollut, 143(1): 117-125.

Lu H M, Yin C Q, Wang W D, Shan B Q, 2007. A comparative study of nutrient transfer via surface runoff from two small agricultural catchments in north China. Environ Geol, 52(8): 1549-1558.

Martin C, Aquilina L, Gascuel-Odoux C, Molenat J, Faucheux M, Ruiz L, 2004. Seasonal and interannual variations of nitrate and chloride in stream waters related to spatial and temporal patterns of groundwater concentrations in agricultural catchments. Hydrol Process, 18(7): 1237-1254.

Rassam D W, Fellows C S, De Hayr R, Hunter H, Bloesch P, 2006. The hydrology of riparian buffer zones; two case studies in an ephemeral and a perennial stream. $J$ Hydrol, 325(1-4): 308-324.

Takatert N, Sanchez-Perez J M, Tremolieres M, 1999. Spatial and temporal variations of nutrient concentration in the groundwater of a floodplain: effect of hydrology, vegetation and substrate. Hydrol Process, 13(10): 1511-1526.

Wang D J, Lin J H, Sun R J, Xia L Z, Lian G, 2003. Optimal nitrogen rate for a high productive rice-wheat system and its impact on the groundwater in the Taihu lake area. Acta Pedologica Sinica, 40(3): 426-432.

Zhang W L, Tian Z X, Zhang N, Li X Q, 1996. Nitrate pollution of groundwater in northern China. Agr Ecosyst Environ, 59(3): 223-231. 